\title{
Factors Behind Growth for India and China- A Access for the Period of 1981-2017
}

\author{
Amit Chatterjee, Devi Prasad Dash, Ramesh Chandra Das, Subhasis Sen
}

\begin{abstract}
This study examines the growth stories of two emerging giants of global East-India and China for the time period 1980-2017. Using regression models, our results show that FDI has no formidable impact upon the economic growth. Similarly, we find no remarkable significant impact of remittances upon economic growth for both economies. Human capital in India is found to have the better substantial impact upon economic growth compared to China, which infers that regime plays a key role in influencing growth mechanism. More importantly, the present study shows that rather than delving exclusively to foreign capital inflows, improving domestic investment cycle and rationing the domestic industry structure fuel growth and ensure competition in long run. Besides investment factors, other economic factors like gross-savings and inflation also swing economic growth in a noticeable way over the years. For both economies, our empirical results reveal that increase in inflation for a long time period cause significant negative growth dispersions. Like other traditional growth engines, our empirical results show that improvements in transport infrastructure like Air and rail transports exert positive impacts upon the growth. Hence, the study suggests much emphasis on the regional development, inequality, better macroeconomic policies to lift developing economies out of the peril of unsustained economic development in recent years.
\end{abstract}

Keywords : Economic Growth, FDI, India, China, Investment, Inflation, Remittances

\section{INTRODUCTION}

The rising of developing economies in the East especially after 1990s has staggered the economists significantly. Thanks to the rapid globalization, increasing turnaround towards westernising and liberal values, urbanization and privatization have shaped the economic growth in East notably in last 3 decades. For many developing economies, globalization has especially turned out to be the helping hand in terms of foreign capital inflow and mobility of people, thus leading to the rising remittances over the years. The growth tales from these perspectives something proves to be specials with the sudden turn arounds in culture, institutions and politics. In certain aspects, these globalization initiatives are treated as the stepping stones of development in the East. Several theoretical and empirical literature have viewed globalization and several economic factors like institutions, rising domestic investment, remittances, improvements in domestic productivity and remittances as the factors behind economic development (Shetty, 2007; Huang and Khanna, 2003; Basu and Maertens, 2007; Abdih et al, 2012).

This paper contributes to the existing literature in following ways. First, it closely looks at the comparative analyses of different development factors in developing economies like India and China. It might be possible that impacts of development in both economies may not be equal. However, a comparative analysis gives the glimpse of the growth in developing economies. Second, few studies consider the factors like inflation, savings, investment and economic growth in the analysis of growth. However, this study has considered the economic factors along with the transport infrastructure and remittances, which impact the growth momentum of the economy sufficiently. Third, the study has exclusively looked into the both economies by considering data from 1980 onwards. It covers mostly the growth momentum post reforms in both economies including several crises and macro-economic changes undergone. This empirical analysis further captures the realistic picture of the developing economies including the impacts of several economic crises like Asian financial crisis and Global financial crisis of 2008.

The main hypothesis of this study is that growth in both India and China is sporadic post-reform era especially after 1980s.

The empirical estimation for this study is considered with the utmost precaution by incorporating regression models. In order to avoid ambiguity and potential bias in the estimation, all variables are converted into the natural logarithm. The rest of the paper is organized as follows. Section-II deals with the literature part of the study. Section-III deals with the data analysis and econometric procedure. Section-IV discusses the results. Section-V concludes the findings.

Revised Manuscript Received on September 10, 2019.

Amit Chatterjee*, School of Economics, MIT-WPU, Pune, Maharashtra, India.

(Email: chatvitamit@gmail.com)

Devi Prasad Dash, School of Economics, MIT-WPU, Pune,

Maharashtra, India.

(Email: devi100.dash@gmail.com)

Ramesh Chandra Das, Department of Economics with Rural

Development, Vidyasagar University, Midnapur, West Bengal, India.

(Email: ramesh051073@gmail.com)

Subhasis Sen, Faculty, SCMHRD, Symbiosis International (Deemed University), Pune, Maharashtra, India.

(Email: subhasis_sen@scmhrd.edu) 


\section{LITERATURE REVIEW}

\begin{tabular}{|c|c|c|c|c|c}
\hline Authors & $\begin{array}{c}\text { Year } \\
\text { of } \\
\text { Study }\end{array}$ & Context & Technique & Subjects & Result \\
\hline $\begin{array}{c}\text { ongwanich and } \\
\text { Kohpsiboon } \\
(2019)\end{array}$ & $\begin{array}{c}1993 \\
-\end{array}$ & $\begin{array}{c}\text { Developing } \\
\text { Asia and } \\
\text { Pacific } \\
\text { Economies }\end{array}$ & $\begin{array}{c}\text { Panel Systen } \\
\text { Gegression }\end{array}$ & $\begin{array}{c}\text { Remittances, } \\
\text { capital inflow } \\
\text { and economic } \\
\text { growth }\end{array}$ & $\begin{array}{c}\text { Remittan } \\
\text { negatively at } \\
\text { growth below } \\
\text { beyond that } \\
\text { impact on gr }\end{array}$ \\
\hline
\end{tabular}

\begin{tabular}{|c|c|c|c|c|c|}
\hline Authors & $\begin{array}{l}\text { Year } \\
\text { of } \\
\text { Study }\end{array}$ & Context & Technique & Subjects & Results \\
\hline $\begin{array}{c}\text { Acosta et } \\
\text { al } \\
(2008)\end{array}$ & $\begin{array}{c}1991 \\
- \\
2005\end{array}$ & $\begin{array}{c}67 \\
\text { Latin } \\
\text { American } \\
\text { Economies }\end{array}$ & $\begin{array}{c}\text { Instrumental } \\
\text { variable } \\
\text { regression } \\
\text { model }\end{array}$ & $\begin{array}{c}\text { Remittances } \\
\text { and economic } \\
\text { growth }\end{array}$ & $=\begin{array}{c}\text { Remittances } \\
\text { positively } \\
\text { impact the } \\
\text { growth }\end{array}$ \\
\hline $\begin{array}{c}\text { Ang and } \\
\text { Madesn } \\
(2011)\end{array}$ & $\begin{array}{c}1953 \\
- \\
2006\end{array}$ & $\begin{array}{c}6 \text { Asian } \\
\text { Economies }\end{array}$ & $\begin{array}{l}\text { Endogenous } \\
\text { growth model }\end{array}$ & $\begin{array}{c}\text { Productivity } \\
\text { trend and } \\
\text { knowledge } \\
\text { production in } \\
\text { growth }\end{array}$ & $\begin{array}{c}\text { Research and } \\
\text { development } \\
\text { have positive } \\
\text { impacts on } \\
\text { growth }\end{array}$ \\
\hline $\begin{array}{c}\text { Catrinescu } \\
\text { et al } \\
(2009)\end{array}$ & $\begin{array}{c}1970 \\
- \\
2003\end{array}$ & $\begin{array}{c}162 \\
\text { countries }\end{array}$ & $\begin{array}{c}\text { Dynamic } \\
\text { Data } \\
\text { Panel Model }\end{array}$ & $\begin{array}{c}\text { Remittances, } \\
\text { Institutions } \\
\text { and Economic } \\
\text { Growth }\end{array}$ & $\begin{array}{l}\text { Remittances } \\
\text { exert a weakly } \\
\text { positive } \\
\text { impact on } \\
\text { long-term } \\
\text { economic } \\
\text { growth }\end{array}$ \\
\hline $\begin{array}{l}\text { Madsen et } \\
\text { al (2010) }\end{array}$ & $\begin{array}{c}1993 \\
- \\
2005\end{array}$ & India & $\begin{array}{c}\text { Johansen } \\
\text { Cointegration } \\
\text { tests }\end{array}$ & $\begin{array}{l}\text { Indian growth } \\
\text { miracle and } \\
\text { endogenous } \\
\text { growth }\end{array}$ & $\begin{array}{l}\text { Growth in Indis } \\
\text { is driven by the } \\
\text { research } \\
\text { intensity and } \\
\text { R\&D } \\
\text { expenditure }\end{array}$ \\
\hline $\begin{array}{c}\text { Demurger } \\
(2001)\end{array}$ & $\begin{array}{c}1985 \\
- \\
1998\end{array}$ & $\begin{array}{c}24 \\
\text { Chinese } \\
\text { states }\end{array}$ & $\begin{array}{l}\text { Panel } \\
\text { regression } \\
\text { model }\end{array}$ & $\mid \begin{array}{c}\text { Transport } \\
\text { infrastructure } \\
\text { and economic } \\
\text { growth }\end{array}$ & $\begin{array}{c}\text { Transport } \\
\text { infrastructure } \\
\text { contributes to } \\
\text { economic } \\
\text { growth }\end{array}$ \\
\hline $\begin{array}{c}\text { Pradhan } \\
\& \\
\text { Bagchi } \\
(2010)\end{array}$ & $\begin{array}{c}1970 \\
- \\
2010\end{array}$ & India & VECM & $\begin{array}{c}\text { Transport } \\
\text { infrastructure } \\
\text { and economic } \\
\text { growth }\end{array}$ & $\begin{array}{c}\text { Bi-directional } \\
\text { causality } \\
\text { between road } \\
\text { transportation } \\
\text { and economic } \\
\text { growth }\end{array}$ \\
\hline $\begin{array}{c}\text { Karagoz } \\
(2009)\end{array}$ & $\begin{array}{c}1970 \\
- \\
2005\end{array}$ & Turkey & $\begin{array}{c}\text { Panel Data } \\
\text { Model \& ADF } \\
\text { Unit Root Test }\end{array}$ & $\begin{array}{c}\text { Workers' } \\
\text { Remittances } \\
\text { and Economic } \\
\text { Growth }\end{array}$ & $\begin{array}{c}\text { Remittances } \\
\text { have negative } \\
\text { affects on } \\
\text { economic } \\
\text { growth of } \\
\text { Turkey }\end{array}$ \\
\hline $\begin{array}{c}\text { Giuliano } \\
\text { and } \\
\text { Arranz } \\
(2009)\end{array}$ & $\begin{array}{c}1975 \\
- \\
2002\end{array}$ & $\begin{array}{c}100 \\
\text { Developing } \\
\text { Countries }\end{array}$ & $\begin{array}{l}\text { OLS \& System } \\
\text { Generalized } \\
\text { Method of } \\
\text { Moments } \\
\text { Regressions } \\
\text { (SGMM) }\end{array}$ & $\begin{array}{c}\text { Remittances, } \\
\text { Financial } \\
\text { Development } \\
\text { and Growth }\end{array}$ & $\begin{array}{c}\text { Remittances } \\
\text { boost economid } \\
\text { growth in } \\
\text { countries that } \\
\text { have shallowe } \\
\text { financial } \\
\text { systems }\end{array}$ \\
\hline
\end{tabular}

Source: Author's own compilation of previous studies.

\section{EMPIRICAL ESTIMATION}

To investigate the role of several factors in terms of analyzing the economic growth, our empirical growth equation can be expressed as follows,

$E G=f(F D I, G F C, R E M, R A I L, A I R, H C, I N F, G S)$
The above equation (1) presents the functional form of economic growth. EG gives the notion of India's and China's economic growth. FDI is the described as the foreign capital inflows. GFC is the gross fixed capital formation. REM is the remittance of both countries. Rail and Air are the both transport infrastructures. HC is the human capital of the economies. INF and GS are the inflation and gross-savings of the economies. Our empirical regression covers the time period from 1980 to 2017 (38 years). Our time regression function is described as

$$
\begin{aligned}
E G_{t}= & \alpha F D I_{t}+\beta G F C_{t}+\gamma R E M_{t}+\delta R A I L_{t}+\theta A I R_{t}+\partial H C_{t} \\
& +\mu I N F_{t}+\sigma G S_{t}+e_{t}
\end{aligned}
$$

In equation (2), $E G$ is the economic growth, the main outcome variable of the study. $F D I$ is the major explanatory variable of the study. Rest all variables are considered as the control variables of the study, where $\alpha, \beta, \gamma, \delta, \theta, \partial, \mu$ and $\sigma$ are the coefficients of FDI, GFC, REM, RAIL, AIR, HC, INF and $G S$ respectively. $e_{t}$ is the error term of the equation (2). FDI, GFC, REM, RAIL, AIR, HC, INF and GS are described as the foreign direct investment, gross fixed capital investment, remittances, rail density, air transport, human capital, inflation and gross-savings respectively. FDI is described as the foreign capital inflows annually into the economy. $t$ is the time of the economies considered over the years. GFC is the gross fixed capital formation, which mainly covers the domestic capital formation. REM is the remittance, which refers to the residents sending money to their homeland from abroad annually. Empirical literature justifies the linear and non-linear relation between remittances and economic growth over the years (Charmi et al, 2006, Charmi et al, 2009, Hassan et al, 2012). This study has also considered the impacts of transport infrastructures upon economic growth. We exclusively consider both air and train the potential agents for transport infrastructures in the economy. Human capital $(H C)$ indicates the total numbers of productive labor forces working in the economy annually. Likewise, other economic factors like inflation and gross-savings act as the key factors for economic growth. Inflation is mainly defined as the increase in price level for two consecutive quarters. Gross-saving is defined as the total savings of the households in the economy annually. For the sake of eradicating spurious relation, we have converted all the variables into the natural logarithms.

Our empirical regression equation has been analysed by considering the joint interaction effect of both air and rail services upon the economy. To explore the impacts of more transport infrastructures upon growth, a separate interaction impact are incorporated by multiplying both air and rail networks. The empirical equation after interaction is represented as follows: 


$$
\begin{aligned}
E G_{t}= & \alpha F D I_{t}+\beta G F C_{t}+\gamma R E M_{t}+\delta\left(R A I L_{t} \times A I R_{t}\right) \\
& +\partial H C_{t}+\mu I N F_{t}+\sigma G S_{t}+e_{t}
\end{aligned}
$$

All the variables of the above study is taken from the World Development Indicators Database of World Bank. Farhadi (2015) examines the association between transport infrastructure, TFP and economic growth for 18 OECD economies over the period 1870-2009 and finds that improvements in transport infrastructure leads to the growth in total factor productivity and labor productivity over the year. We posit that improvements of both air and train connectivity will result in more economic development in long run.

\section{INTERPRETATION OF RESULTS}

Table 4.1 below gives the glance of average variation, maximum and minimum trend in several economic factors and GDP growth in both India and China.

\begin{tabular}{|c|c|c|c|c|c|c|c|c|}
\hline \multicolumn{9}{|c|}{ Descriptive Statistics for China and India } \\
\hline & EG & FDI & REM & GFC & RAII & AIR & INF & GS \\
\hline Mean & 1.011 & 1.009 & 0.958 & 1.611 & 4.633 & 7.711 & 0.641 & 1.543 \\
\hline Median & 1.017 & 1.065 & 1.003 & 1.611 & 4.760 & 7.726 & 0.703 & 1.610 \\
\hline S.D & 0.120 & 0.244 & 0.234 & 0.048 & 0.748 & 0.693 & 0.438 & 0.378 \\
\hline $\operatorname{Max}$ & 1.207 & 1.095 & 1.066 & 1.687 & 4.827 & 8.741 & 1.334 & 1.726 \\
\hline Min & 0.690 & 0.000 & 0.000 & 1.527 & 0.000 & 0.490 & -0.968 & 0.000 \\
\hline Nation & \multicolumn{8}{|c|}{ China } \\
\hline \multirow[t]{2}{*}{$\begin{array}{c}\text { No of } \\
\text { Obs }\end{array}$} & 38 & 38 & 38 & 38 & 38 & 38 & 38 & 38 \\
\hline & EG & FDI & REM & GFC & RAIL & AIR & INF & GS \\
\hline Mean & 0.846 & 1.008 & 1.042 & 1.476 & 4.800 & 7.347 & 0.879 & 1.420 \\
\hline Median & 0.875 & 1.020 & 1.042 & 1.460 & 4.797 & 7.211 & 0.941 & 1.439 \\
\hline S.D & 0.144 & 0.048 & 0.022 & 0.090 & 0.009 & 0.382 & 0.166 & 0.125 \\
\hline Max & 1.051 & 1.066 & 1.037 & 1.638 & 4.822 & 8.145 & 1.168 & 1.574 \\
\hline $\operatorname{Min}$ & 0.313 & 0.889 & 1.014 & 1.328 & 4.786 & 6.819 & 0.487 & 1.177 \\
\hline Nation & \multicolumn{8}{|c|}{ India } \\
\hline $\begin{array}{c}\text { No of } \\
\text { Obss }\end{array}$ & 38 & 38 & 38 & 38 & 38 & 38 & 38 & 38 \\
\hline
\end{tabular}

\section{Table-4.1 Descriptive Statistics}

Source: Author's own estimation

To explore the relationship between economic growth and FDI in both China and India, we work with time series data for the comparative study of India and China. We use the following data for 38 years period from 1980 to 2017. All variables are converted into natural $\log$. The mean variation in economic growth is higher in China compared to India during this period. FDI variation in China and India is almost same. India has comparatively performed better in terms of remittances than China because of the high concentration in the Indian expats in abroad. Compared to India, China has developed domestic sector far ahead of India.

\begin{tabular}{|c|c|c|c|c|}
\hline $\begin{array}{c}\text { Economic } \\
\text { Growth }\end{array}$ & Model I & Model II & Model III & Model IV \\
\hline$F D I$ & $\begin{array}{c}0.445 \\
(0.401)\end{array}$ & $\begin{array}{c}-0.988 \\
(0.982)\end{array}$ & $\begin{array}{c}0.565 \\
(0.563)\end{array}$ & $\begin{array}{c}0.315 \\
(0.219)\end{array}$ \\
\hline$G F C$ & $\begin{array}{l}1.196^{\circ} \\
(0.583)\end{array}$ & & $\begin{array}{l}0.990^{8} \\
(0.546)\end{array}$ & $\begin{array}{l}1.220^{8} \\
(0.570)\end{array}$ \\
\hline Remittances & $\begin{array}{l}-1.168 \\
(1.021)\end{array}$ & $\begin{array}{c}1.014 \\
(1.012)\end{array}$ & $\begin{array}{l}-0.461 \\
(0.427)\end{array}$ & $\begin{array}{l}-1.479 \\
(1.473)\end{array}$ \\
\hline Rail & $\begin{array}{c}0.017 \\
(0.015)\end{array}$ & $\begin{array}{c}0.029 \\
(0.027)\end{array}$ & $\begin{array}{c}0.009 \\
(0.008)\end{array}$ & $\begin{array}{c}0.010 \\
(0.012)\end{array}$ \\
\hline Air & $\begin{array}{c}-0.284 \\
(0.267)\end{array}$ & $\begin{array}{l}0.312^{8} \\
(0.104)\end{array}$ & $\begin{array}{c}-0.118 \\
(0.108)\end{array}$ & $\begin{array}{c}-0.244 \\
(0.245)\end{array}$ \\
\hline $\begin{array}{l}\text { Human } \\
\text { Capital }\end{array}$ & $\begin{array}{c}0.432 \\
(0.417)\end{array}$ & $\begin{array}{l}-0.794^{8} \\
(0.326)\end{array}$ & $\begin{array}{c}0.024 \\
(0.025)\end{array}$ & $\begin{array}{c}0.297 \\
(0.292)\end{array}$ \\
\hline Inflation & $\begin{array}{c}0.052 \\
(0.053)\end{array}$ & $\begin{array}{c}0.058 \\
(0.056)\end{array}$ & & \\
\hline $\begin{array}{l}\text { Gross } \\
\text { Savings }\end{array}$ & $\begin{array}{c}0.600 \\
(0.601)\end{array}$ & $\begin{array}{c}0.074 \\
(0.073)\end{array}$ & & $\begin{array}{c}0.881 \\
(0.758)\end{array}$ \\
\hline Nation & \multicolumn{4}{|c|}{ China } \\
\hline $\begin{array}{c}\text { No of } \\
\text { observations }\end{array}$ & 37 & 37 & 37 & 37 \\
\hline$R^{2}$ & 0.271 & 0.166 & 0.222 & 0.254 \\
\hline Adjusted $R^{2}$ & 0.096 & 0.006 & 0.100 & 0.110 \\
\hline
\end{tabular}

Table-4.2 (Regression Result for China)

Source-Author's own computation of results. All variables are transferred into natural $\log . *, * *$ and $* * *$ denote the estimates that are significantly different from zero at $1 \%, 5 \%$ and $10 \%$ levels of significance respectively.

\begin{tabular}{|c|c|c|c|c|}
\hline $\begin{array}{l}\text { Economic } \\
\text { Growth }\end{array}$ & Model I & Model II & Model III & Model IV \\
\hline$F D I$ & $\begin{array}{c}0.364 \\
(0.359)\end{array}$ & $\begin{array}{c}0.251 \\
(0.242)\end{array}$ & $\begin{array}{c}0.218 \\
(0.224)\end{array}$ & $\begin{array}{c}0.499 \\
(0.496)\end{array}$ \\
\hline$G F C$ & $\begin{array}{l}1.445^{*} \\
(0.540)\end{array}$ & $\begin{array}{l}1.224 * 8 * 8 \\
(0.795)\end{array}$ & $\begin{array}{c}0.849 * 8 * \\
(0.516)\end{array}$ & \\
\hline Remittances & $\begin{array}{c}1.384 \\
(1.252)\end{array}$ & $\begin{array}{l}1.520 \\
(1.136)\end{array}$ & $\begin{array}{c}0.865 \\
(0.863)\end{array}$ & $\begin{array}{l}2.783 \\
(2.283)\end{array}$ \\
\hline Rail & $\begin{array}{l}-0.560 \\
(0.533)\end{array}$ & $\begin{array}{l}-0.645 \\
(0.673)\end{array}$ & $\begin{array}{l}-0.383 \\
(0.369)\end{array}$ & $\begin{array}{c}-1.050 \\
(0.850)\end{array}$ \\
\hline Air & $\begin{array}{c}0.197 \\
(0.170)\end{array}$ & $\begin{array}{c}0.272 \\
(0.259)\end{array}$ & $\begin{array}{c}0.112 \\
(0.102)\end{array}$ & $\begin{array}{l}0.485^{*} \\
(0.224)\end{array}$ \\
\hline $\begin{array}{l}\text { Human } \\
\text { Capital }\end{array}$ & $\begin{array}{c}-0.849^{8 *} \\
(0.470)\end{array}$ & $\begin{array}{l}-1.085 \\
(0.785)\end{array}$ & $\begin{array}{l}-0.302 \\
(0.256)\end{array}$ & $\begin{array}{l}-1.728^{*} \\
(0.679)\end{array}$ \\
\hline Inflation & $\begin{array}{c}-0.473 * \\
(0.195)\end{array}$ & $\begin{array}{l}-0.518^{*} \\
(0.230)\end{array}$ & & $\begin{array}{l}-0.554^{*} \\
(0.234)\end{array}$ \\
\hline Gross-savings & & $\begin{array}{c}0.423 \\
(0.400)\end{array}$ & & $\begin{array}{l}1.650^{8} \\
(0.774)\end{array}$ \\
\hline $\begin{array}{c}\text { No of } \\
\text { observations }\end{array}$ & 38 & 38 & 38 & 38 \\
\hline Nation & \multicolumn{4}{|c|}{ India } \\
\hline$R^{2}$ & 0.359 & 0.363 & 0.238 & 0.312 \\
\hline Adjusted $R^{2}$ & 0.235 & 0.214 & 0.119 & 0.179 \\
\hline
\end{tabular}

Table 4.3 (Regression result for India)

Published By: 
Source-Author's own computation of results. All variables are transferred into natural $\log$. *, ** and *** denote the estimates that are significantly different from zero at $1 \%, 5 \%$ and $10 \%$ levels of significance respectively.

\section{A. In the presence of Interaction}

The following table reports the simple regression result in the presence of interaction effect of transport infrastructure in case of China. So far China is concerned, our estimated results do not any formidable association between FDI and growth in presence of interaction (see columns I, II and III). Most of the FDI inflows are highly concentrated in the coastal regions of China. Since our data tend to vary in different dimensions, we convert them into natural log. Our empirical results posit no significant relation between remittances and growth during the considered period. However, we find very surprising trend in models II and III in terms of declining economic growth in case of improvements in human capital. It indicates the high presence of authoritarian regimes in local, state and federal levels. When considering the effects with and without remittances, we notice that every $1 \%$ increase in domestic investment leads to $0.587 \%$ to $0.698 \%$ increase in the economic growth annually (see models II and III). Overall our R2 results show very lesser correlation among the variables with the economic growth. It reflects that growth has no such formidable relation with the factors considered over the time period. Although growth in developing economies has been found to be exceedingly high, still these are biased and unbalanced.

Table 4.4: Analysis for China in Presence of Interaction

\begin{tabular}{|c|c|c|c|}
\hline Economic Growth & Model I & Model II & Model III \\
\hline FDI & $\begin{array}{c}-0.920 \\
(0.847)\end{array}$ & $\begin{array}{c}-0.173 \\
(0.168)\end{array}$ & $\begin{array}{c}-0.290 \\
(0.249)\end{array}$ \\
\hline \multirow{2}{*}{ Remittances } & 1.363 & -0.243 & \\
& $(1.267)$ & $(0.227)$ & \\
\hline \multirow{2}{*}{ Human capital } & $0.170^{8}$ & $-0.188^{8 *}$ & $-0.184^{88}$ \\
& $(0.065)$ & $(0.106)$ & $(0.102)$ \\
\hline \multirow{2}{*}{ Rail ${ }^{*}$ Air } & $0.254^{8}$ & 0.047 & 0.051 \\
& $(0.058)$ & $(0.042)$ & $(0.045)$ \\
\hline Inflation & $0.153^{* 8}$ & 0.045 & 0.049 \\
& $(0.054)$ & $(0.043)$ & $(0.048)$ \\
\hline \multirow{2}{*}{ Gross savings } & -0.156 & 0.381 & 0.305 \\
& $(0.152)$ & $(0.297)$ & $(0.278)$ \\
\hline \multirow{2}{*}{ Gross Fixed Capital } & & $0.698^{*}$ & $0.587^{8}$ \\
\hline County & China & China & China \\
\hline No of obsenvations & 37 & 37 & 37 \\
\hline$R^{2}$ & 0.138 & 0.249 & 0.248 \\
\hline Adjusted $R^{2}$ & 0.122 & 0.099 & 0.127 \\
\hline
\end{tabular}

Source-Author's own computation of results. All variables are transferred into natural $\log$. *, ** and *** denote the estimates that are significantly different from zero at $1 \%, 5 \%$ and $10 \%$ levels of significance respectively.

Table 4.5 describes the growth function of India in the presence of transport infrastructure. From above 3 models, we do not find any significant evidence of FDI and growth relation. Similarly, we find no association between remittances and growth. An improvement in human capital is rather found to be having the surprising negative impact upon growth. It indicates that growth across the Indian states might not be uniform. Joint interaction effect of transport has a large positive and significant impact upon the economic growth (See model II). Every $1 \%$ increase in the transport sector leads to the $8.2 \%$ increase in growth annually. Furthermore, our estimation reveals that every $1 \%$ increase in inflation drags economic growth by $0.5 \%$ across models on an average (see models I to III). It sufficiently indicates that an improvement in inflationary growth has a long term negative impact on the economic growth. In addition to this, our empirical results posit that improvements in domestic investment cycle as proxied by gross fixed capital exhibit positive and significant impact upon the economic growth (see models I and III).

Table 4.5: Analysis for India in presence of interaction

\begin{tabular}{|c|c|c|c|}
\hline Economic Growth & Model I & Model II & Model III \\
\hline FDI & $\begin{array}{c}0.265 \\
(0.264)\end{array}$ & $\begin{array}{c}0.520 \\
(0.517)\end{array}$ & $\begin{array}{c}0.401 \\
(0.380)\end{array}$ \\
\hline Remittances & $\begin{array}{c}2.399 \\
(2.376)\end{array}$ & $\begin{array}{c}3.517 \\
(3.050)\end{array}$ & \\
\hline Human capital & $\begin{array}{c}-1.177 \\
(0.829)\end{array}$ & $\begin{array}{c}-1.835^{*} \\
(0.728)\end{array}$ & $\begin{array}{c}-1.012 \\
(0.737)\end{array}$ \\
\hline Rail*Air & $\begin{array}{c}4.493 \\
(4.494)\end{array}$ & $\begin{array}{c}8.236^{*} \\
(3.294)\end{array}$ & $\begin{array}{c}4.817 \\
(4.338)\end{array}$ \\
\hline Inflation & $-0.522^{8}$ & $-0.554^{*}$ & $-0.509 *$ \\
$(0.229)$ & $(0.234)$ & $(0.225)$ \\
\hline Gross savings & $\begin{array}{c}0.411 \\
(0.385)\end{array}$ & $\begin{array}{c}1.663^{*} \\
(0.774)\end{array}$ & $\begin{array}{c}-0.360 \\
(0.354)\end{array}$ \\
\hline Gross Fixed Capital & $1.248^{* 88}$ & & $1.301^{* 8}$ \\
& $(0.779)$ & & $(0.762)$ \\
\hline Country & India & India & India \\
\hline No of observations & 38 & 38 & 38 \\
\hline$R^{2}$ & 0.365 & 0.365 & 0.360 \\
\hline Adjusted $R^{2}$ & 0.217 & 0.217 & 0.237 \\
\hline
\end{tabular}

Source: Author's own computation of results. All variables are transferred into natural $\log$. $*$, ** and $* * *$ denote the estimates that are significantly different from zero at $1 \%, 5 \%$ and $10 \%$ levels of significance respectively.

\section{B. Comparative Regression Result Analysis}

Our empirical results show that FDI inflows to China are comparatively higher than India. Every $1 \%$ increase in FDI inflows results in $0.24 \%$ to $0.4 \%$ growth in India, while it leads to $0.4 \%$ to $0.9 \%$ growth in China annually. Although China has undergone the authoritarianism, still it has liberalized the FDI rules sufficiently and encouraged more foreign capitals to invest in coastal China in recent years. Furthermore, the role of remittance is not found to be that much appealing to economic growth for both economies. However, the magnitude of remittances inflow in recent years for India is higher than that of China. It is because of the concentration of more NRIs in western hemisphere and

Published By:

Blue Eyes Intelligence Engineering \& Sciences Publication

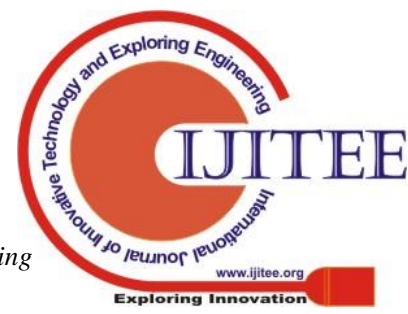


the Indian worker classes in Middle East. Improvements in transport infrastructure have found to be pronounced positive impacts for both economies. However, China in terms of transport infrastructure is way ahead of India. While considering the exclusive airline sector, our regression results show that China has made quite robust development in aviation industry during these years. Due to the major shift in industrial policy regime and more regioncentric economic development, India has performed way ahead of China in terms of channelizing domestic investment more for the economic growth. As evident from our regression results, this study shows that every $1 \%$ increase in domestic investment (gross fixed capital) has led to $0.5 \%-0.6 \%$ economic growth in China, while it leads to more than $1.2 \%$ growth in India during this period. In addition to this, declining human capital quality in terms of various opportunities and economic livelihood is a serious issue for both these economies. Our empirical results reveal that every $1 \%$ increase in human capital has rather led to the declining economic growth for both economies, which indirectly shows the presence of under-employment, no effective labour laws, faulty regime systems, corruption, prevalence of under-paid employees, gruelling working conditions and lack of proper labour market regulation.

\section{CONCLUSION}

This paper examined the impacts of several economic factors upon the economic growth for both India and China for the period 1980-2017. This study is a genuine attempt to unravel the myth of economic growth for the developing economies of East. More specifically, we sought to examine the impacts of various factors like remittances, FDI, gross fixed investment, inflation, gross savings, human capital and transport upon the growth. More specifically, we notice that improvements in human capital tend to decline growth in some empirical instances for both the economies. It directly indicates that growth pattern has not been uniformly concentrated across the regions and shift in political regime may not be dynamic enough to capture and address the local growth. In some instances, we get the visible impacts of improvements in transport infrastructure and domestic investment cycle and their resultant impacts upon the economic growth. Although, we do not find any noticeable impacts of FDI and remittances upon growth for both economies, still the importance of traditional growth engines like foreign capital inflow and remittances cannot be ruled out. Both countries in addition to this, must seek for a proper balanced macroeconomic strategy to counteract the rising inflation issue over the years, in order to restore more sustainable growth, developing economies must maintain the robust domestic investment cycle as well as channelize the remittances and gross domestic savings to fuel the regional economic growth more in long run. The biggest issue in both China and India is that regional growth is highly unbalanced and bizarrely unequal over the years.

Although this paper has not looked into the issue of regional growth parity, still it will provide enough scope to enlarge the horizon of addressing comparative regional and local development of the developing economies in the coming years.

\section{REFERENCES}

1. Abdih, Y., Chami, R., Dagher, J., \& Montiel, P. (2012). Remittances and institutions: Are remittances a curse? World Development, 40(4), 657-666.

2. Acosta, P., Calderon, C., Fajnzylber, P., \& Lopez, H. (2008). What is the impact of international remittances on poverty and inequality in Latin America?. World Development, 36(1), 89-114.

3. Ang, J. B., \& Madsen, J. B. (2011). Can secondgeneration endogenous growth models explain the productivity trends and knowledge production in the Asian miracle economies?. Review of Economics and Statistics, 93(4), 1360-1373.

4. Basu, K., \& Maertens, A. (2007). The pattern and causes of economic growth in India. Oxford Review of Economic Policy, 23(2), 143-167.

5. Chami, R. T. Cosimano and M. Gapen [2006],"Beware of Emigrants Bearing Gifts: Optimal Fiscal and Monetary Policy in the Presence of Remittances" (No. 06/61). IMF Working Paper.

6. Démurger, S. (2001). Infrastructure development and economic growth: an explanation for regional disparities in China?. Journal of Comparative Economics, 29(1), 95117.

7. Giuliano, P., \& Ruiz-Arranz, M. (2009). Remittances, financial development, and growth. Journal of Development Economics, 90(1), 144-152.Catrinescu, N., Leon-Ledesma, M., Piracha, M., \& Quillin, B. (2009). Remittances, institutions, and economic growth. World Development, 37(1), 81-92.

8. Huang, Y., \& Khanna, T. (2003). Can India overtake china?. Foreign Policy, 137(July-August), 74-81.

9. Jongwanich, J., \& Kohpaiboon, A. (2019). Workers Remittances, Capital Inflows, and Economic Growth in Developing Asia and the Pacific. Asian Economic Journal, 33(1), 39-65.

10. Karagöz, K. (2009). Workers' Remittances and Economic Growth: Evidence From Turkey. Journal of Yaşar University, 4(13), 1891-1908.

11. Madsen, J. B., Saxena, S., \& Ang, J. B. (2010). The Indian growth miracle and endogenous growth. Journal of Development Economics, 93(1), 37-48.

12. Pradhan, R. P., \& Bagchi, T. P. (2013). Effect of transportation infrastructure on economic growth in India: the VECM approach. Research in Transportation Economics, 38(1), 139-148.

\section{AUTHORS PROFILE}

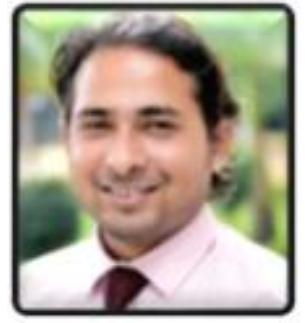

Amit Chatterjee is currently serving as Assistant Professor at School of Economics, MIT-WPU, Pune, Maharashtra, India with more than four years of teaching and research experience majorly in Development and Monetary Economics. He. has also worked as Editor for McGraw Hill in more than 60 books related to various courses of Economics at UG and PG levels for different universities namely, University of Calcutta, Mumbai, Madras and Bangalore University. 


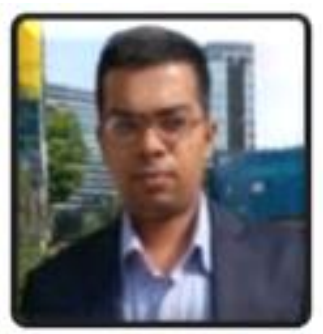

national and international repute.

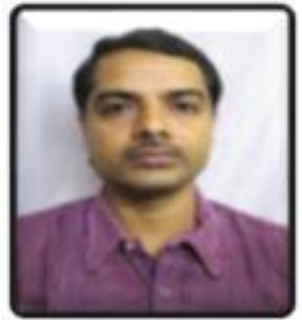

Devi Prasad Dash is currently serving as Assistant Professor at School of Economics, MIT-WPU, Pune Maharashtra, India with more than four years of teaching and research experience majorly in Health \& Urban Economics. Dr. Devi has been awarded doctorate degree in Economics from IIT Ropar and has presented papers at

Ramesh Chandra Das is currently Associate Professor of Economics at Vidyasagar University, West Bengal, India with twenty years of teaching and research experience in different fields of the subject. He has obtained Masters, M. Phil and Ph. D. Degree in Economics from the University of Calcutta. He has contributed several research papers to national and international journals with a list of text and edited books published by international and national publishers. His areas of research lie in macroeconomics, quantitative economics and environmental economics.

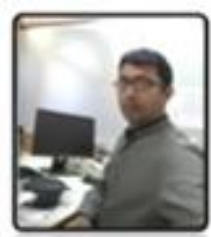

Subhasis Sen earned his B.Com. (Hons.), MBA from Jadavpur University, M.Phil. from Bharati Vidyapeeth Pune and $\mathrm{PhD}$ in Business Management from University of Calcutta and is associated with SCMHRD, Symbiosis International (Deemed University) Pune and Life Member, The Indian Econometric Society (TIES). His professional interests include Sales and Distribution Management, Services Marketing, Sports Marketing and Strategic Marketing Decisions. He has published research papers in prestigious journals of national and global repute like Survey, Indian Journal of Marketing, Prabandhan and Global Journal of E-business \& Knowledge Management. 